\title{
ANALISIS PENYELAMATAN ARSIP SENIMAN DAN KELOMPOK SENI MELALUI AKUISISI ARSIP DI DINAS PERPUSTAKAAN DAN KEARSIPAN DIY
}

\author{
Velin Ulvandhia ${ }^{1}$, Rina Rakhmawati ${ }^{2}$, Faizatush Sholikhah ${ }^{3}$ \\ 1,2,3Program Studi Diploma Kearsipan, Sekolah Vokasi, Universitas Gadjah Mada \\ velin.ulvandhia@mail.ugm.id; rinaarsip@ugm.ac.id; faizatush.sholikhah@ugm.ac.id
}

\begin{abstract}
Artists and art groups's archives are representations of artistic activities in the Special Region of Yogyakarta. This paper analyzes the process of archival acquisition of artists and art groups as an effort to preserve arts memory in the Special Region of Yogyakarta. Dinas Perpustakaan dan Kearsipan Daerah Istimewa Yogyakarta carries out the acquisition of archives of artists and art groups in 2018. Data that used in this research are primary data (observation of participation and interviews) and secondary data (literature review). One of researchers is observing the process of archival acquisition started from August 2018. Interview are conducted by interviewing archivists involved in acquisition activities with the aim of completing data and getting more complete information from resource persons who are experts in the activity. The literature review uses references including books, internet sources, and guidelines used by Dinas Perpustakaan dan Kearsipan Daerah Istimewa Yogyakarta. The data is processed using a data triangulation approach. The conclusion of this paper is the procedure of acquisition carried out by the Dinas Perpustakaan dan Kearsipan Daerah Istimewa Yogyakarta based on Peraturan Kepala Arsip Nasional RI Nomor 31 Tahun 2011 tentang Tata Cara Akuisisi Arsip Statis. However, there are some limitations in its implementation. They are the technical aspects of archive acquisition, archive acquisition policy, facilities and infrastructure.
\end{abstract}

Keywords: archives, acquisition, artists, art groups, preservation

\section{Intisari}

Arsip seniman dan kelompok seni menjadi representasi dari kegiatan berkesenian di Daerah Istimewa Yogyakarta. Makalah ini menganalisis proses akuisisi arsip seniman dan kelompok seni sebagai upaya melestarikan memori berkesenian di Daerah Istimewa Yogyakarta. Dinas Perpustakaan dan Kearsipan Daerah Istimewa Yogyakarta melaksanakan kegiatan akuisisi arsip seniman dan kelompok seni pada tahun 2018. Data yang digunakan dalam penelitian berupa data primer (observasi partisipasi dan wawancara) dan data sekunder (kajian pustaka). Pengamatan dilaksanakan secara langsung terhadap prosedur akuisisi arsip bidang kesenian. Wawancara campuran dilaksanakan dengan mewawancarai pihak yang terkait dalam kegiatan akuisisi dengan tujuan melengkapi data-data dan mendapatkan informasi lebih lengkap dari narasumber yang ahli dalam kegiatan tersebut. Kajian pustaka yaitu menggunakan referensi meliputi buku, sumber internet, dan pedoman yang digunakan oleh Dinas Perpustakaan dan Arsip Daerah Daerah Istimewa Yogyakarta. Data tersebut diolah dengan pendekatan triangulasi data. Kesimpulan dari makalah ini adalah prosedur akuisisi yang dilaksanakan oleh Dinas Perpustakaan dan Kearsipan DIY didasarkan pada Peraturan Kepala Arsip Nasional RI Nomor 31 Tahun 2011 tentang Tata Cara Akuisisi Arsip Statis. Meskipun demikian, dalam implementasinya terdapat penyesuaian. Kendala yang terjadi saat proses akuisisi, yaitu pada aspek teknis akuisisi arsip, kebijakan akuisisi arsip, sarana dan prasarana.

Kata kunci: arsip, akuisisi, seniman, kelompok seni, penyelamatan 


\section{PENDAHULUAN}

Dinamika berkehidupan manusia melahirkan budaya. Budaya adalah daya dari budi yang berarti cipta, karsa, dan rasa sedangkan kebudayaan adalah hasil dari proses cipta, karsa, dan rasa tersebut (Widagdho, 2010). E.B Tylor menyatakan bahwa, kebudayaan adalah keseluruhan kompleks, yang di dalamnya terkandung ilmu pengetahuan yang lain, serta kebiasaan yang didapat manusia sebagai anggota masyarakat (dalam Widagdho, 2010). Kebudayaan memiliki karakteristik berbeda di setiap daerah. Kebudayaan terdiri dari 7 unsur, yaitu sistem pengetahuan, religi, bahasa, sistem mata pencaharian hidup, sistem organisasi sosial, teknologi, dan kesenian (Koentjaraningrat, 1983).

Kesenian adalah ciptaan dari segala pikiran dan perilaku manusia yang fungsional, estetis, dan indah, sehingga ia dapat dinikmati dengan pancaindranya (Koentjaraningrat, 2005). Kesenian dibagi menjadi beberapa jenis seni, seperti seni rupa, seni musik, seni tari, seni pertunjukan, dan seni sastra. Seni diciptakan oleh pelaku seni atau seniman, yakni seorang penutur kisah, menggunakan baik fiksi maupun kebenaran, melalui media lukisan perunggu, film fotografis, dan benda-benda lainnya, untuk menafsirkan dan menggambarkan perasaan serta ide-ide (Krystal dan Soetrisno, 2010). Dalam melakukan kerja seni seniman, selain menciptakan karya seni yang, tidak sedikit seniman yang mendokumentasikan proses berkeseniannya. Karya seni, proses berkeseniannya hingga rekam jejak perjalanan hidup sang seniman dan kelompok seninya dapat dikatakan sebagai arsip.

Dalam pendekatan ilmu kearsipan, arsip seniman dan kelompok seni dikategorikan sebagai arsip personal atau perseorangan. Arsip seniman dan kelompok seni dimanfaatkan sebagai materi pengkajian seni, inspirasi dan motivasi berkesenian bagi generasi ke generasi, sekaligus digunakan oleh seniman dalam mengklaim hak atas karya intelektual dibidang seni. Selain itu, arsip seniman dan kelompok seni memberi wawasan bagaimana seorang seniman atau sebuah kelompok seni bergulat menyajikan dan mengelaborasi kerja seninya. Akan tetapi, penanganan arsip bidang seniman dan kelompok seni masih dipandang belum sesuai dengan kaidah kearsipan yang bertujuan agar arsip dapat dimanfaatkan secara terus menerus dimasa mendatang. Pengelolaan arsip seniman dan kelompok seni, khususnya di Daerah Istimewa Yogyakarta dilakukan baik oleh seniman dan kelompok seni itu sendiri hingga komunitas kearsipan yang bergerak di penyelematan arsip kesenian, seperti Indonesia Visual Arts Archive (IVAA). Selain itu, dilandasi adanya kemanfaatan arsip seniman dan kelompok seni bagi banyak pihak, pemerintah, dalam hal ini lembaga kearsipan daerah turut serta melaksanakan upaya penyelamatan arsip seniman dan kelompok seni. Tujuan utama dari lembaga kearsipan daerah menyelamatkan arsip seniman dan kelompok seni adalah sebagai upaya menjaga memori berkesenian suatu daerah. Apalagi Yogyakarta telah dikenal sebagai kota kebudayaan. Memori berkesenian adalah kemampuan mengingat kembali suatu aktivitas atau pengalaman pelaku seni dalam menghasilkan suatu karya seni. Apabila arsip seniman dan kelompok seni telah diselamatkan, dikelola, dan dipelihara, serta dihidupkan, maka arsip dapat dimanfaatkan bagi kepentingan skala luas secara maksimal.

Akuisisi arsip merupakan salah 
satu wujud penyelamatan arsip bernilai kesejarahan. Pada tahun 2018, Dinas Perpustakaan dan Arsip Daerah Istimewa Yogyakarta telah melaksanakan kegiatan akuisisi arsip seniman dan kelompok seni di Daerah Istimewa Yogyakarta. Adapun pertanyaan penelitian yang diajukan adalah bagaimana proses penyelamatan arsip seniman dan kelompok seni melalui akuisisi arsip di Dinas Perpustakaan dan Kearsipan Daerah Istimewa Yogyakarta?

\section{METODE PENELITIAN}

Penelitian ini merupakan jenis penelitian deskriptif analisis dengan pendekatan studi kasus. Data yang digunakan terdiri dari data primer (observasi partisipasi dan wawancara) dan data sekunder (kajian pustaka). Dalam pelaksanaan observasi partisipasi, peneliti ikut serta dalam kegiatan akuisisi arsip seniman dan kelompok seni yang dilaksanakan Seksi Pengelolaan Arsip di Dinas Perpustakaan dan Arsip Daerah Daerah Istimewa Yogyakarta. Wawancara dilaksanakan dengan narasumber tim arsiparis yang tergabung dalam panitia akuisisi arsip dan Kepala Bidang Pelestarian dan Layanan Arsip, serta arsiparis yang bertanggung jawab dalam kegiatan akuisisi arsip seniman dan kelompok seni di Dinas Perpustakaan dan Arsip Daerah Istimewa Yogyakarta. Untuk melengkapi data hasil observasi dan wawancara, kajian pustaka dilakukan dengan mengacu pada buku-buku kearsipan dan artikel pada jurnal. Data diolah dengan pendekatan triangulasi data.

Kajian mengenai akuisisi arsip belum masif dilakukan, baik oleh akademisi maupun praktisi kearsipan. Kegiatan akuisisi merupakan upaya penelusuran dan seleksi arsip yang memiliki nilai kesejarahan. Faktor yang mempengaruhi pelaksanaan akuisisi arsip salah satunya adalah status kelembagaan pengelola arsip. Menurut Rakhmawati dkk. (2018) lembaga kearsipan pemerintah memiliki cakupan pengelolaan arsip bernilai kesejarahan di lingkup pemerintahan, sedangkan sektor swasta, komunitas hingga perseorangan, tidak seharusnya diwajibkan untuk menyerahkan arsip bernilai kesejarahannya kepada lembaga kearsipan. Namun demikian dalam konteks Indonesia, prosedur tersebut masih perlu dikaji ulang. Hal ini karena kondisi kesadaran, pengetahuan, dan pemahaman publik, terutama komunitas dan perseorangan, terhadap kegiatan pengarsipan, belum dapat dikatakan mampu menyelamatkan arsip guna pelestarian jangka panjang. Maka, lembaga kearsipan, sebagai institusi yang secara legal dan intelektual memiliki kompetensi mengelola arsip sesuai kaidah kearsipan, sudah semestinya menyelamatkan arsip-arsip yang diciptakan oleh perseorangan maupun komunitas.

\section{HASIL DAN PEMBAHASAN}

Menurut Basuki $(2017,97)$, akuisisi adalah proses penambahan koleksi arsip dengan cara menerima materi kearsipan sebagai sumbangan, transfer, pembelian, ataupun pinjaman. Akuisisi dalam pandangan Basuki tersebut dapat disebut sebagai akuisisi pasif. Dalam konteks kearsipan Indonesia saat ini, lembaga kearsipan dituntut untuk aktif, tidak sebatas menunggu pihak eksternal menyerahkan arsipnya. Dalam istilah kearsipan, lembaga kearsipan yang aktif mengumpulkan maupun menelusuri arsip bernilai kesejarahan disebut dengan akuisisi aktif. Konsep tersebut juga dapat dicermati pada definisi akuisisi menurut Crush (dalam Bettington, 2007, 207), yaitu the process with acquiring records that are relavant to your archives (proses mengakuisisi arsip yang sesuai dengan cakupan kewenangan lembaga kearsipannya). Dalam pelaksanaannya, 
proses akuisisi tidak sebatas mengumpulkan, menelusuri kemudian membawa ke lembaga kearsipan. Basuki $(2017,97)$ memaparkan tahapan proses akuisisi, yaitu:

1. Penilaian yang jelas tentang ruang lingkup, kekuatan, dan kelemahan koleksi yang ada terhadap garis haluan (policy) akuisisi

2. Identifikasi sumber materi kearsipan yang secara potensial akan memperkuat atau mengembangkan koleksi arsip

3. Penyusunan strategi untuk memperoleh materi kearsipan

4. Penerimaan akuisisi secara resmi.

Berbeda dengan konsep yang banyak dipahami arsiparis maupun akademisi di Indonesia, Duranti dan Franks (2015) menjabarkan proses akuisisi terdiri dari: from the development of an acquisition policy, appraisal, and negotiations with creators, through to the transfer and receipt of physical custody and the accessioning of records. Dalam konsep Duranti dan Franks, proses akuisisi tidak kemudian selesai pada saat penerimaan, namun berlanjut hingga proses aksesioning. Dengan demikian, konsep akuisisi tersebut hanya sebatas penelusuran arsip, sedangkan proses peralihan kewenangan pengelolaannya ada pada tahap aksesioning. Menurut Shapley (dalam Bettington, 208, 226), aksesioning adalah the process of controlling records in your custody by gathering and recording information about them. Proses aksesioning juga diperlukan untuk menyusun skala prioritas tahap selanjutnya, yaitu pengolahan arsip statis. Aksesioning dalam implementasinya berupa pendataan fisik dan informasi arsip secara singkat dalam suatu daftar. Arsip yang telah diaksesioning, jika tidak memiliki sifat kerahasiaan, dapat dimanfaatkan oleh pengguna tanpa harus menunggu proses pengolahan arsipnya.
Pada dasarnya, konsep kegiatan aksesioning telah dilaksanakan oleh Dinas Perpustakaan dan Arsip Daerah Istimewa Yogyakarta saat mengakuisisi arsip seniman dan kelompok seni.

Pada tahun 2018, Dinas Perpustakaan dan Arsip Daerah DIY telah melaksanakan kegiatan akuisisi arsip seniman dan kelompok seni di lingkup Wilayah Yogyakarta. Kegiatan akuisisi arsip berpedoman pada . Berdasarkan pedoman tersebut, proses akuisisi dapat dicermati pada bagan berikut:

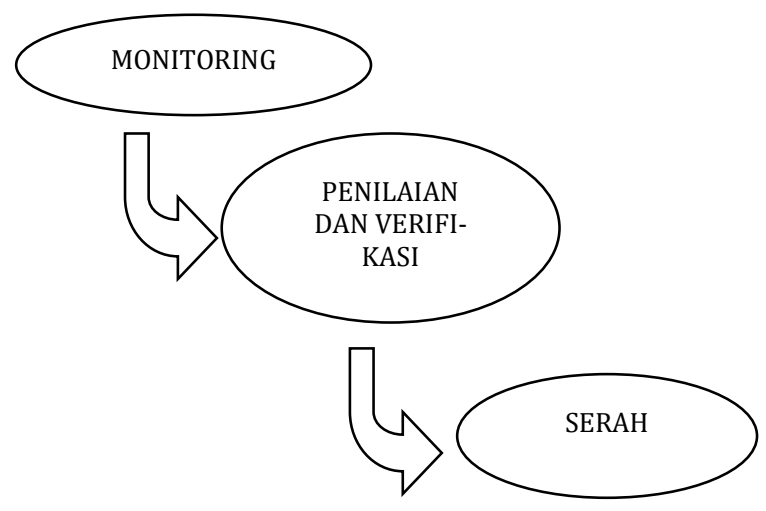

Bagan 1. Alur Akuisisi Arsip Statis

Dalam Peraturan Kepala ANRI tersebut, tahapan aksesioning terjabarkan secara implisit ke dalam salah satu tahapan serah terima arsip statis. Serah terima dalam konteks peraturan tersebut berkaitan dengan peralihan hak tanggung jawab atas pengelolaan arsip dari pencipta arsip ke lembaga kearsipan dan pengolahan awal arsip hasil akuisisi sebelum masuk pada tahapan pengolahan arsip statis. Berdasarkan Peraturan Kepala ANRI, tahapan pelaksanaan akuisisi arsip seniman dan kelompok seni oleh Seksi Pengelolaan Arsip di Dinas Perpustakaan dan Arsip Daerah DIY adalah sebagai berikut:

\section{Monitoring}

Monitoring dalam kegiatan akuisisi dilakukan dengan cara penelusuran pada pencipta arsip (creating agency) dan 
pemilik arsip (owner). Sebelum dilakukan penelusuran, tim akuisisi terlebih dahulu melakukan perencanaan. Dalam perencanaan yang disusun, target pencipta dan pemilik arsip yang akan diakuisisi sejumlah 20 yang terdiri dari seniman dan kelompok seni. Penetapan jumalh tersebut disesuaikan dengan kemampuan sumber daya manusia, sarana prasarana, dan penganggaran yang telah direncanakan. Berdasarkan hasil wawancara, penentuan kriteria pencipta arsip yang akan diakuisisi arsipnya oleh Seksi Pengelolaan yaitu seniman sudah sepuh atau meninggal, menghasilkan banyak karya seni berkualitas, berkesenian minimal di lingkup Wilayah Yogyakarta, kelompok seni masih eksis dengan hasil karya seni banyak dan berkualitas, dan berkesenian minimal di Wilayah Yogyakarta, serta kelompok seni yang masih ada penanggung jawab atau pengurus organisasi. Dalam analisis peneliti, kriteria tersebut masih dinilai belum jelas dan tegas indikatornya, seperti rentang waktu usia tua, banyaknya karya seni, kualitas karya seni. Dengan demikian, potensi subjektivitas semakin besar. Seksi Pengelolaan Arsip juga mendapatkan 15 rekomendasi pencipta arsip dari UPT Taman Budaya. Selain itu, Seksi Pengelolaan Arsip mencari 5 pencipta arsip secara mandiri melalui website (www.jogjabudaya.com/ qdata.php) dan buku kebudayaan dari

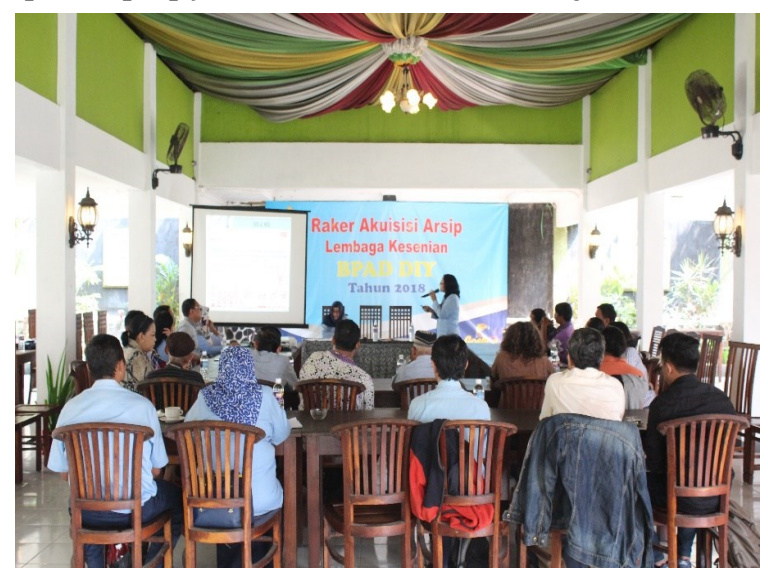

Gambar 1. Rapat Kerja Akuisisi Arsip Dinas Perpustakaan dan Kearsipan Daerah Istimewa Yogyakarta
Dinas Kebudayaan DIY untuk melengkapi jumlah target pencipta arsip yang akan diakuisisi. Setelah dilakukan pendataan target akuisisi, Seksi Pengelolaan Arsip mengundang 20 pencipta arsip tersebut untuk ikut serta dalam rapat kerja akuisisi arsip. Rapat kerja dilaksanakan pada tanggal 28 Agustus 2018 di Goebog Resto Jalan Wonosari KM.1, Banguntapan, Pringgolayan, Banguntapan, Bantul, Daerah Istimewa Yogyakarta.

Dalam rapat kerja tersebut, Dinas Perpustakaan dan Arsip Daerah DIY menjelaskan akan pentingnya pendokumentasian karya seni, pentingnya arsip, tujuan dari kegiatan akuisisi arsip bidang kesenian, teknis akuisisi arsip, dan jadwal kunjungan tim akuisisi arsip. Dinas Perpustakaan dan Arsip Daerah DIY secara tidak langsung juga melakukan negosiasi agar seniman dan kelompok seni bersedia menyerahkan arsipnya dengan cara meyakinkan seniman dan kelompok seni bahwa arsip yang diserahkan akan dijaga dan dikelola berdasarkan standar pengelolaan arsip serta sarana prasarana yang memadai. Meski demikian, proses negosiasi tidak seharusnya dilakukan dalam satu kali pertemuan dan dalam forum yang formal mengingat target akuisisi adalah seniman dan kelompok seni. Akan tetapi, ada beberapa pencipta arsip yang tidak dapat hadir dalam rapat kerja akuisisi arsip sehingga tim akuisisi arsip menghubungi pencipta arsip untuk melakukan kunjungan langsung dan menerangkan secara sederhana maksud dan tujuan Dinas Perpustakaan dan Arsip Daerah DIY dalam mengakuisisi arsip bidang keseniannya. Namun demikian, terdapat beberapa pencipta arsip yang akhirnya dihapus dalam daftar target dan diganti dengan pencipta arsip lain dengan alasan tidak melaksanakan pengumpulan dan pendataan arsip. Persoalan komunikasi juga menjadi pertimbangan dalam perubahan target akuisisi sebab 
pencipta arsip tidak hadir saat rapat kerja akuisisi arsip sehingga tim akuisisi arsip mengalami kesulitan dalam mengubungi pencipta arsip. Dalam analisis peneliti, pendekatan yang intensif dan informal justru lebih mendekatkan seniman dan kelompok seni dengan kearsipan sekaligus menanamkan kesadaran untuk tertib arsip.

Setelah rapat kerja akuisisi arsip, dilakukan kunjungan secara langsung. Dalam kunjungan tersebut, tim akuisisi arsip memberikan penjelasan ulang mengenai arsip yang akan diakuisisi dan melihat secara langsung kondisi lapangan terkait sejauh mana pencipta arsip sudah melakukan pengumpulan dan pendataan arsip yang akan diserahkan. Durasi kunjungan oleh tim akuisisi arsip relatif berbeda antar pencipta arsip. Hal ini, bergantung pada karakter dari pencipta arsip dan waktu selesainya pengumpulan dan pendataan arsip oleh pencipta arsip bersangkutan.

\section{Penilaian dan Verifikasi}

Penilaian arsip statis dilakukan oleh lembaga kearsipan dalam rangka menyeleksi arsip yang telah dinyatakan habis masa retensinya dan/atau berketerangan permanen oleh pencipta arsip. Berdasarkan Peraturan Kepala ANRI Nomor 31 Tahun 2011 tentang Tata Cara Akuisisi Arsip Statis, berikut hal yang perlu diketahui dalam melakukan penilaian arsip statis, antara lain:

a. Penilaian arsip dalam akuisisi menggunakan pendekatan makro dengan mengedepankan tema sosial (social issues) sehingga dimungkinkan informasi arsip tersebut, tidak hanya terdapat pada satu pencipta arsip saja tetapi terdapat di beberapa pencipta arsip.

b. Penilaian arsip didasarkan analisis fungsi organisasi

c. Penilaian arsip substansi informasi d. Penilaian arsip didasarkan analisis karakteristik fisik

e. Penilaian terhadap arsip bentuk khusus (seperti: foto, film/video, kaset, kartografi dan gambar keasitekturan serta juga arsip elektronik) berbeda dengan cara penilaian arsip yang dilakukan terhadap arsip media kertas. Untuk arsip bentuk khusus yang merupakan lampiran atau informasi pendukung dari arsip media kertas maka proses penilaiannya menyatu dengan penilaian arsip media kertas dengan mengikuti JRA/JRD.

Dalam pedoman tersebut, tidak dijelaskan secara spesifik arsip seniman dan kelompok seni, sehingga tim akuisisi arsip menyusun secara mandiri jenis arsip yang dapat diakuisisi dari seniman dan kelompok seni. Dalam kasus ini, metode penilaian yang digunakan pada arsip sektor publik tidak dapat diterapkan begitu saja pada arsip seniman dan kelompok seni. Hal tersebut mengingat tujuan dan substansi operasional kelembagaan yang berbeda. Seniman dan kelompok seni dapat dikategorikan sebagai lembaga independen yang tidak sekaku organisasi publik dalam operasional kegiatannya. Oleh karena perbedaan prinsip kelembagaan, maka penelusuran arsipnya pun tidak dapat disamakan dengan penelusuran arsip pada organisasi publik. Penyusunan jenis arsip juga berdasarkan pada analisis nilaiguna sekunder. Arsip bernilaiguna sekunder adalah arsip yang didasarkan bagi kepentingan skala luas mencakup pencipta arsip, kepentingan umum, dan penyelenggaraan kehidupan kebangsaan maka tidak boleh dimusnahkan, sehingga harus dilestarikan oleh lembaga kearsipan. Berdasarkan Keputusan Kepala Arsip Nasional Republik Indonesia Nomor 07 Tahun 2001 tentang Pedoman Penilaian Arsip Bagi Instansi Pemerintah, 
Badan Usaha, dan Swasta nilaiguna sekunder terbagi menjadi 2 nilaiguna, diantaranya:

a. Nilaiguna evidential/kebuktian

b. Nilaiguna informasional

Disamping itu, berdasarkan

Peraturan Gubernur Daerah Istimewa Yogyakarta Nomor 19 Tahun 2013 tentang Perubahan Atas Peraturan Gubernur Daerah Istimewa Yogyakarta Nomor 12 Tahun 2010 tentang Pengelolaan Arsip Statis, arsip yang bernilaiguna sekunder, yaitu:

a. Arsip yang bernilaiguna kebuktian (evidensial)

b. Arsip yang bernilaiguna informasional

Penyusunan jenis arsip oleh tim akuisisi arsip bertujuan agar memudahkan lingkup arsip seniman dan kelompok seni yang dapat diakuisisi. Namun apabila pencipta arsip mengalami kesulitan, maka tim akuisisi arsip dapat membantu melaksanakan pendataan arsip pada waktu kunjungan berlangsung. Adapun jenis arsip yang menjadi target akuisisi dapat dicermati pada tabel berikut:

Tabel 1. Rapat

\begin{tabular}{|l|l|}
\hline No. & Jenis Arsip \\
\hline 1. & $\begin{array}{l}\text { Dokumen pendirian lembaga/ } \\
\text { paguyuban seni }\end{array}$ \\
\hline 2. & Susunan kepengurusan \\
\hline 3. & Profil lembaga/paguyuban seni \\
\hline 4. & $\begin{array}{l}\text { Dokumen aset lembaga/paguyuban } \\
\text { seni }\end{array}$ \\
\hline 5. & $\begin{array}{l}\text { Arsip tokoh dari lembaga/ } \\
\text { paguyuban seni }\end{array}$ \\
\hline 6. & $\begin{array}{l}\text { Naskah-naskah yang berkaitan } \\
\text { dengan aktivitas seni yang dil- } \\
\text { aksanakan }\end{array}$ \\
\hline 7. & Penghargaan yang pernah diterima \\
\hline 8. & Dokumentasi kegiatan (foto/video) \\
\hline
\end{tabular}

Verifikasi dilakukan terhadap arsip statis yang tercantum di JRA yang berketerangan dipermanenkan serta terhadap arsip yang belum tercantum dalam JRA tetapi memiliki nilaiguna kesejarahan dengan didukung oleh buktibukti berdasarkan ketentuan peraturan perundang-undangan. Verifikasi arsip dibagi menjadi dua, yakni verifikasi secara langsung dan verifikasi secara tidak langsung. Akuisisi arsip jenis verifikasi secara tidak langsung, artinya verifikasi yang dilakukan apabila pencipta arsip berbentuk lembaga/ organisasi atau perseorangan belum memiliki JRA atau JRD. Penilaian arsip seniman dan kelompok seni memang tidak dapat didasarkan pada Jadwal Retensi Arsip. Bahkan dapat dikatakan bahwa arsip seniman dan kelompok seni merupakan arsip bentuk khusus yang memiliki nilai permanen sejak arsip diciptakan sehingga tidak memiliki retensi spesifik sebagaimana arsip pada organisasi publik. Bahkan jika dicermati pada pengelolaan arsip seni di Indonesia Visual Arts Archive (IVAA) tidak terdapat istilah penyusutan sebab arsip-arsip yang berhasil diselamatkan memiliki nilai kesejarahan dan pengetahuan sehingga mutlak dipermanenkan.

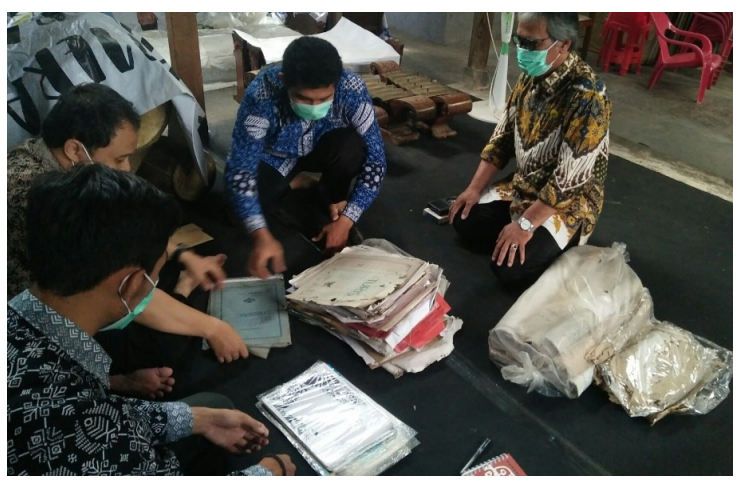

Gambar 2. Kunjungan Tim Akuisisi Arsip ke Pencipta Arsip

Pada saat kunjungan, tim akuisisi arsip melakukan pemeriksaan antara data yang telah disusun oleh pencipta arsip dengan fisik arsip. Namun oleh karena penilaian hanya berbasis model penilaian arsip sektor publik, maka prosesnya dinilai belum dilaksanakan 


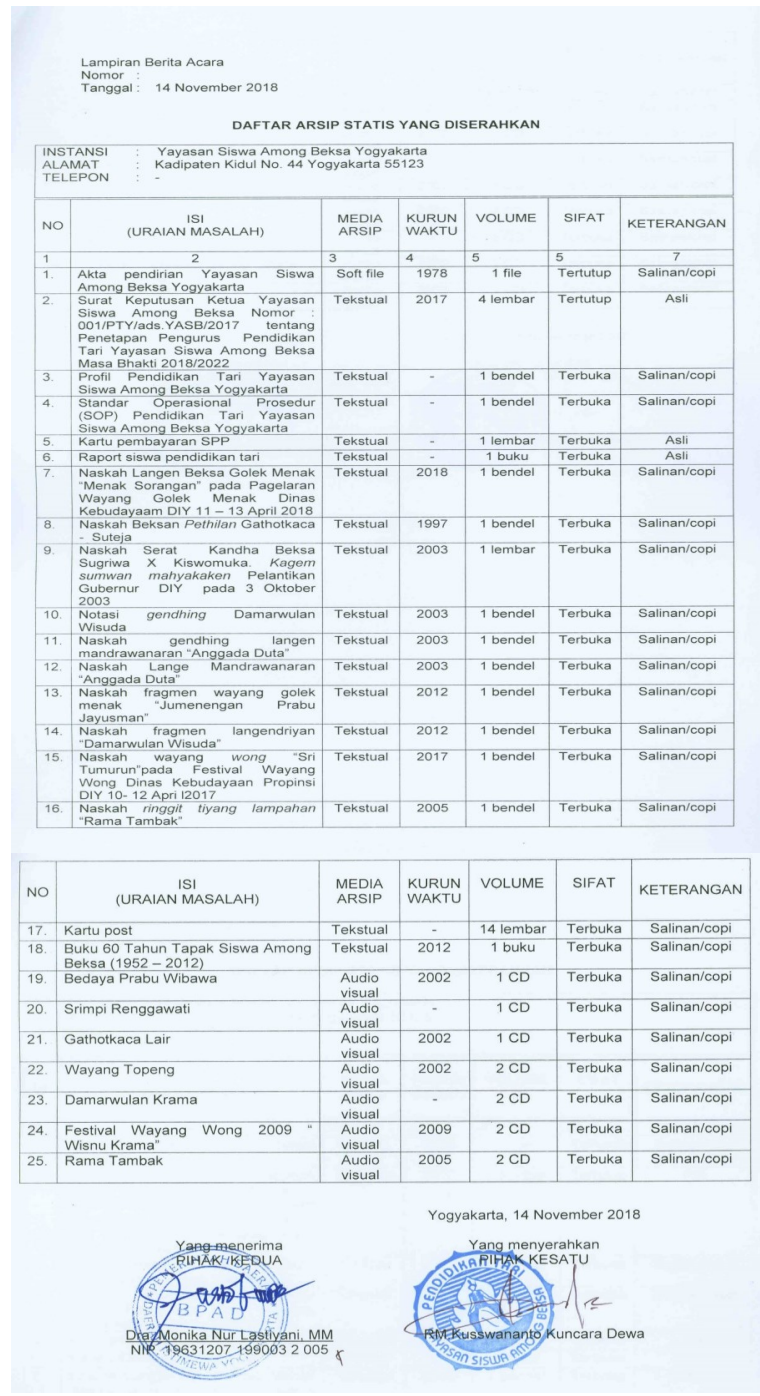

Gambar 3. Hasil Alih Media Daftar Arsip yang Diserahkan Yayasan Siswa Among Beksa Yogyakarta

secara maksimal karena tim akuisisi arsip masih berpedoman pada susunan jenis arsip yang dapat diserahkan oleh pencipta arsip, sehingga tim akuisisi arsip menyimpulkan bahwa arsip tersebut bernilaiguna sekunder atau permanen. Hal tersebut, bertujuan untuk mengefisienkan waktu kegiatan akuisisi arsip agar dapat selesai tepat waktu dengan hasil target sasaran sesuai dengan perencanaan. Sebenarnya, tahapan penilaian merupakan tahapan yang paling penting dalam mengakuisisi arsip yang bernilaiguna sekunder. Apabila arsip yang diakuisisi tidak bernilaiguna sekunder maka akan terjadi ketidakefektifan dan keefisienan dalam tahapan pengolahan. Selain itu juga berpotensi terjadi pemborosan untuk pelestarian arsip yang tidak bernilaiguna sekunder.

Berdasarkan daftar arsip pada gambar 3, dapat dicermati bahwa proses penilaian belum dilakukan secara maksimal artinya tim akuisisi arsip harus melakukan penilaian terhadap arsip berdasarkan nilaiguna arsip menentukan apakah arsip bernilaiguna sekunder atau tidak. Dalam kasus arsip yang diserahkan dari Yayasan Siswa Among Beksa pada gambar 1, pada nomor (6) terdapat rapot siswa pendidikan tari dan nomor (17) terdapat kartu pos seharusnya tidak termasuk arsip yang bernilaiguna sekunder karena tidak memiliki nilai kebuktian/evidensial atau informasional. Hal ini dapat dicermati pada aspek informasi, rapot siswa tersebut kosong atau tidak terdapat informasi siswa didik, begitupula dengan nomor (17) tidak terdapat informasi didalamnya sehingga secara tidak langsung pada tahapan pemeriksaan oleh tim akuisisi arsip belum dilaksanakan secara optimal.

Setelah dilakukan penilaian, tim akuisisi arsip membuat surat penetapan status arsip statis oleh lembaga kearsipan, surat persetujuan untuk menyerahkan arsip statis dari pencipta arsip ke lembaga kearsipan, penetapan arsip statis yang diserahkan oleh pencipta arsip, daftar arsip statis yang diserahkan, dan berita acara penyerahan arsip statis. Hal tersebut juga diatur Peraturan Pemerintah RI Nomor 28 Tahun 2012 tentang Pelaksanaan Undang -undang Nomor 43 Tahun 2009 tentang Kearsipan pada pasal 92 bahwa tahapan prosedur akuisisi arsip statis terdapat tahapan menetapkan status arsip statis oleh lembaga kearsipan, persetujuan untuk menyerahkan oleh pencipta arsip, penetapan arsip statis yang diserahkan oleh pimpinan pencipta arsip, pelaksanaan serah terima arsip statis oleh pimpinan pencipta arsip kepada 
kepala lembaga kearsipan disertai dengan berikut:

berita acara dan daftar arsip statis yang diserahkan. Berdasarkan Peraturan Kepala ANRI Nomor 31 Tahun 2011 tentang Tata Cara Akuisisi Arsip Statis pada tahapan verifikasi hanya terdiri dari pembuatan penetapan status arsip statis dan penyusunan daftar arsip statis.

Dalam implementasinya, penyusunan penetapan status arsip statis oleh lembaga kearsipan, persetujuan untuk menyerahkan arsip statis, penetapan arsip statis yang diserahkan oleh pencipta arsip dilaksanakan bersamaan dengan berita acara dan daftar arsip statis yang diserahkan. Pada prinsipnya, pembuatan dokumen akuisisi arsip di atur pada Peraturan Pemerintah RI Nomor 28 Tahun 2012 tentang Pelaksanaan Undang-undang Nomor 43 Tahun 2009 tentang Kearsipan pada pasal 92 bahwa surat penetapan status arsip statis harus disusun oleh lembaga kearsipan dan pencipta arsip secara mandiri, surat persetujuan untuk menyerahkan arsip statis harus disusun oleh pencipta arsip, dan berita acara serta daftar arsip statis yang diserahkan harus disusun oleh pencipta arsip. Akan tetapi, hanya sebagian pencipta arsip yang menyusun dokumen akuisisi arsip secara mandiri berdasarkan contoh dari hasil rapat kerja dan sebagian dibantu oleh tim akuisisi arsip untuk penyusunannya.

\section{Serah Terima Arsip Statis}

Serah terima arsip statis merupakan tahapan terakhir dari kegiatan akuisisi arsip statis yang melibatkan pencipta arsip selaku pihak yang menyerahkan dan lembaga kearsipan selaku pihak yang menerima arsip statis. Dalam prosesnya, serah terima arsip statis terjadi pelimpahan tanggung jawab atau wewenang untuk menyelamatkan dan melestarikan arsip statis dari pencipta arsip kepada lembaga kearsipan. Berdasarkan Peraturan Kepala ANRI Nomor 31 Tahun 2011 tentang Tata Cara Akuisisi Arsip Statis, pelaksanaan serah terima arsip statis perlu mempertimbangkan hal-hal sebagai

a. Persiapan

b. Melakukan koordinasi antara lembaga kearsipan dengan pencipta arsip selaku pihak donor yang akan menyerahkan arsip statisnya

c. Mempersiapkan standarisasi naskah Berita Acara yang disusun sesuai Peraturan Menteri Pendayagunaan Aparatur Negara Nomor 22 Tahun 2008 tentang Pedoman Umum Tata Naskah Dinas

d. Pengiriman/pengangkutan arsip dilakukan setelah penandatanganan naskah berita acara serah terima arsip statis

Dalam konteks ilmu kearsipan, pelimpahan wewenang atau tanggung jawab pengelolaan dari pencipta kepada lembaga kearsipan disebut dengan aksesioning. Selain itu, kegiatan aksesioning juga mencakup tahapan awal pengolahan arsip hasil akuisisi oleh lembaga kearsipan. Pada tahapan ini, tim akuisisi arsip melaksanakan kegiatan peralihan tanggung jawab antara pencipta arsip ke lembaga kearsipan atas pengelolaan arsip yang telah diserahkan berdasarkan penandatanganan berita acara penyerahan arsip statis dan daftar arsip statis yang diserahkan ditempat pencipta arsip. Akan tetapi, penandatanganan tersebut dilaksanakan ketika tahapan verifikasi secara tidak langsung. Setelah dilakukan penandatanganan, tim akuisisi arsip mengangkut arsip statis hasil akuisisi ke Depo Arsip Dinas Perpustakaan dan Arsip Daerah DIY.

Pada tanggal 14 November 2018, diadakan kembali rapat kerja akuisisi arsip di Ruang Rapat Lantai 2 Dinas Perpustakaan dan Arsip Daerah DIY dengan mengundang seluruh pencipta arsip meliputi seniman dan kelompok seni yang arsipnya telah berhasil diakuisisi. Rapat kerja tersebut merupakan agenda seremonial penyerahan arsip statis dari 
Velin Ulvandhia, Rina Rakhmawati, Faizatush Sholikhah pencipta arsip ke lembaga kearsipan. Selain itu, pencipta arsip diberikan kompensasi (tali asih) dari Dinas Perpustakaan dan Arsip Daerah DIY karena bersedia menyerahkan arsip statisnya dan melakukan pendataan arsip.

Terkait pengolahan awal arsip hasil akuisisi, dalam Peraturan Kepala ANRI Nomor 31 Tahun 2011 tentang Tata Cara Akuisisi Arsip Statis, pada tahapan serah terima arsip statis juga menjabarkan pengolahan awal arsip statis yang telah berhasil diakuisisi sebelum masuk tahapan pengolahan arsip statis yang dilakukan sebelum pengangkutan arsip statis hasil akuisisi ke depo arsip. Pada implementasinya, tahapan pengolahan awal ini dijalankan ketika arsip statis yang berhasil diakuisisi sudah di angkut ke depo arsip Dinas Perpustakaan Arsip Daerah DIY. Berikut tahapan pengolahan awal hasil akuisisi arsip bidang kesenian:

a. Uji petik antara daftar arsip statis yang diserahkan dengan fisik arsip

b. Melapisi arsip dengan kertas kising, memberikan keterangan nama pencipta arsip dan nomor urut arsip sesuai daftar arsip statis yang telah diserahkan

c. Menata arsip ke dalam boks arsip

d. Memberikan label pada boks arsip berupa keterangan kegiatan akuisisi, pencipta arsip, nomor arsip dalam boks, dan nomor boks

e. Menata boks arsip ke dalam roll o'pack

Dalam pelaksanaan akuisisi arsip seniman dan kelompok seni yang dilaksanakan pada tahun 2018, Dinas Perpustakaan dan Arsip Daerah DIY terkendala dengan beberapa hal sebagai berikut:

a. Seksi Pengelolaan Arsip mengalami kesulitan dalam mendapatkan pencipta arsip sesuai dengan kriteria penilaian yang ditentukan;

b. Dalam hal negosiasi, tim akuisisi tentang Tata Cara Akuisisi Arsip Statis.

Analisis Penyelamatan Arsip Seniman Seni... arsip belum sepenuhnya mampu membuat pencipta arsip bersedia menyerahkan arsip asli ke Dinas Perpustakaan dan Arsip Daerah DIY;

c. Pada tahapan penilaian dan verifikasi, ada beberapa pencipta arsip yang belum dapat melakukan pendataan arsip dan penyusunan dokumen akuisisi arsip secara mandiri;

d. Tidak berjalannya kunjungan tim akuisisi arsip ke pencipta arsip sesuai dengan jadwal yang telah ditentukan. Hal ini disebabkan, tidak sinkronnya jadwal kunjungan dengan kegiatan dari pencipta arsip sehingga tim akuisisi arsip membuat jadwal kunjungan ulang. Selain itu, terjadi beberapa perubahan target sasaran pencipta arsip menyebabkan tim akuisisi arsip harus menghubungi pencipta arsip dan membuat jadwal kunjungan.

e. Tim akuisisi arsip berhasil mengakuisisi 19 pencipta arsip dengan perencanaan target sasaran berjumlah 20 pencipta arsip. Tim akuisisi arsip masing-masing harus bertanggung jawab pada 5 pencipta arsip dengan waktu kurang dari 3 bulan. Hal ini, sulit dilaksanakan karena tergantung dari kondisi pencipta arsip itu sendiri seperti cepat tidaknya pengumpulan dan pendataan arsip oleh pencipta arsip.

f. Tidak adanya pedoman mengenai apa saja jenis arsip bidang kesenian yang dapat diserahkan sehingga tim akuisisi arsip menyusun sendiri jenis arsip yang dapat diserahkan oleh pencipta arsip.

\section{KESIMPULAN}

Pelaksanaan akuisisi arsip seniman dan kelompok seni oleh lembaga kearsipan di Indonesia mengacu pada Peraturan Kepala ANRI Nomor 31 Tahun 2011 Diplomatika, Vol. 2, No. 2 Maret 2019 
Kegiatan akuisisi tersebut meliputi arsip yang diserahkan di tempat pencipta tahapan monitoring, penilaian dan arsip. Selain itu, pada tahap serah terima verifikasi, dan serah terima arsip statis. arsip statis juga dilaksanakan pengolahan Pada tahap monitoring, Seksi Pengelolaan awal arsip hasil akuisisi oleh Dinas Arsip mempunyai perencanaan target Perpustakaan dan Arsip Daerah DIY sasaran 20 pencipta arsip dengan kurun dengan cara uji petik antara daftar arsip waktu pelaksanaan akuisisi bulan Agustus statis yang diserahkan dengan fisik arsip, - Oktober. Setelah itu, Seksi Pengelolaan melapisi arsip dengan kertas kising Arsip mengundang 20 pencipta arsip dengan memberikan keterangan nama untuk ikut serta dalam rapat kerja akuisisi pencipta arsip dan nomor urut arsip sesuai arsip agar pencipta arsip bersedia daftar arsip statis yang telah diserahkan, menyerahkan arsipnya dan memiliki menata arsip ke dalam boks arsip, gambaran mengenai langkah-langkah yang memberikan label pada boks arsip, dan harus dilakukan untuk ikut serta dalam menata boks arsip ke dalam roll o'pack. kegiatan akuisisi. Dalam implementasinya, beberapa target sasaran pencipta arsip yang perlu diganti sehingga Seksi Pengelolaan Arsip berhasil mengakuisisi 19 pencipta arsip dengan beberapa pencipta arsip yang berubah. Pencipta arsip melakukan pengumpulan arsip dan pendataan arsip berdasarkan jenis arsip yang dapat diserahkan.

Tim akuisisi arsip melaksanakan penilaian arsip berdasarkan daftar jenis arsip yang dapat diserahkan. Pada tahap verifikasi dilaksanakan menggunakan verifikasi secara tidak langsung untuk lembaga/organisasi dan perseorangan. Tahap verifikasi dilaksanakan secara tidak utuh karena penilaian tidak dilaksanakan analisis nilaiguna arsip pada aspek informasinya. Pada tahap verifikasi ini, tim akuisisi arsip menyusun dokumentasi legalisasi akuisisi arsip meliputi surat penetapan status arsip statis oleh lembaga kearsipan, surat persetujuan untuk menyerahkan arsip statis dari pencipta arsip ke lembaga kearsipan, penetapan arsip statis yang diserahkan oleh pencipta arsip, daftar arsip statis yang diserahkan, berita acara penyerahan arsip statis.

Pada tahap terakhir yakni serah terima arsip statis, dilaksanakan secara bersama pada tahap verifikasi arsip. Tim akuisisi arsip melaksanakan kegiatan peralihan tanggung jawab antara pencipta arsip ke lembaga kearsipan atas pengelolaan arsip berdasarkan penandatanganan berita acara dan daftar
Dalam pelaksanaan akuisisi arsip seniman dan kelompok seni oleh Dinas Perpustakaan dan Arsip Daerah DIY, menghadapi beberapa kendala dari teknis akuisisi arsip meliputi mendapatkan pencipta arsip secara tepat, negosiasi dengan pencipta arsip, pendataan arsip, dan jadwal kunjungan arsip. Pada aspek kebijakan akuisisi arsip meliputi 19 pencipta arsip yang berhasil diakuisisi arsipnya, tim akuisisi arsip harus bertanggung jawab pada 5 pencipta arsip dengan karakter yang berbeda, dan tidak ada pedoman mengenai jenis arsip bidang kesenian apa saja yang dapat diserahkan. Selain itu, dari sarana dan prasarana seperti kendaraan dan lokasi mengenai jarak dan tempat pencipta arsip yang sulit dijangkau.

\section{UCAPAN TERIMA KASIH}

Ucapan terima kasih kepada Program Studi Kearsipan Sekolah Vokasi UGM yang telah memberikan kesempatan kepada saya untuk dapat memperdalam ilmu kearsipan dan Dinas Perpustakaan dan Kearsipan Daerah Istimewa Yogyakarta atas kesempatan untuk Praktik Kerja Lapangan (PKL) dan penelitian terkait akuisisi arsip.

\section{DAFTAR PUSTAKA}

Barbara Krystal dan Eddy Soetrisno. (...). 100 Seniman Yang Membentuk Sejarah 
Velin Ulvandhia, Rina Rakhmawati, Faizatush Sholikhah Dunia, Jakarta: Progress

Bettington, Jeckie (ed.). (2008). Keeping Archives, Australia: Australian Society of Archivists Inc.

Committee on Records Management of the Society of American Archivists. (...). Writings on Records Management: A Select List, Amerika: The Society of American Archivists

Duranti, Luciana dan Patricia C. Franks. (2015). Encyclopedia of Archival Science, Amerika: Rowman \& Littlefield

Farah Mariana dan Yoshi Fajar Kresno Murti. (2014). Arsipelago: Kerja Arsip \& Pengarsipan Seni Budaya Indonesia, Yogyakarta: Indonesian Vicual Art Archive (IVAA)

Hadi Abubakar. (1991). Pola Kearsipan Modern: Sistem Kartu Kendali, Jakarta: Djambatan

J. Brichford, Maynard. (1977). Preserves \& Manuscripts: appraisal \& accessioning, Chicago: Society of American Archivists

Keputusan Kepala Arsip Nasional Nuryadani, Wimpi Nabila, dan Yeni Arista. Republik Indonesia Nomor 07 Tahun 2001 (2018). "Arsip Statis Tanggung Jawab tentang Pedoman Penilaian Arsip, Bagi Siapa?" Kajian Perbandingan Konsep Dan Instansi Pemerintah, Badan Usaha, dan Pelaksanaan Akuisisi Arsip Antara Sektor Swasta

"Memori", kbbi.kemdikbud.go.id/entri/memori

(diakses pada tanggal 6 Februari)

Peraturan Gubernur Daerah Istimewa Yogyakarta Nomor 19 Tahun 2013 tentang Perubahan Atas Peraturan Gubernur Daerah Istimewa Yogyakarta Nomor 12 Tahun 2010 tentang Pengelolaan Arsip Statis

Peraturan Kepala Arsip Nasional Republik Indonesia Nomor 31 Tahun 2011 tentang Tata Cara Akuisisi Arsip Statis

Peraturan Pemerintah Republik Indonesia Nomor 28 Tahun 2012 tentang Pelaksanaan Undang-undang Nomor 43 Tahun 2009 tentang Kearsipan

R. Funny Mustikasari Elita.
Analisis Penyelamatan Arsip Seniman Seni...

"Memahami Memori" dalam Mediator: Jurnal Komunikasi. 5(1):147

Read, Judith dan Mary Lea Ginn. (2007). Records Management:Eighth Edition, USA: South-Western Cengage Learning

Rhoads, James B. (1995). The Role of Archives and Records Management in National Information Systems: A Ramp Study. Paris: General Information Programme and UNISIST

Sambas Ali Muhidin dan Hendri Winata. 2016. Manajemen Kearsipan untuk Organisasi Publik, Bisnis, Sosial, Politik, dan Kemasyarakatan. Bandung: CV Pustaka Setia

Sulistyo Basuki. (2017). Pengantar Kearsipan. Papua: Penerbit Aseni

Suwartono. (2014). Dasar-dasar Metodologi Penelitian. Yogyakarta: CV Andi Offset

Undang-Undang Nomor 43 Tahun 2009 tentang Kearsipan

Rakhmawati, Rina, Fatimah Wahyu Publik Dengan Sektor Swasta. Jurnal Khizanah al-Hikmah, 6 (2), 141-154. 